学術論文

\title{
変調波磁束を用いたスクリュモータの提案
}

\section{A Novel Magnetic Screw Motor Utilizing a Modulated Magnetic Flux}

\author{
高原 一晶*1 (学生員), 平田 勝弘 ${ }^{* 1}$ (正員), 新口 昇 ${ }^{* 1}$ (正員)
}

Kazuaki TAKAHARA (Stu Mem.), Katsuhiro HIRATA (Mem.), Noboru NIGUCHI (Mem.)

\begin{abstract}
A feed screw mechanism is used in various machines and robots. Mechanical screws such as ball and slide screws have various problems due to their mechanical frictions. In order to solve these problems, a magnetic screw which is one of contactless screws has been proposed. Nowadays, magnetic screw motors which a magnetic screw is integrated with a motor are proposed. However, these screw motors require permanent magnets in their mover, and the volume of the permanent magnets increases as the stroke increases. In this paper, in order to solve these problems, a magnetic screw motor whose permanent magnets are in its stator is proposed. The static characteristics of the proposed motor is investigated using 3-D finite element analysis.
\end{abstract}

Keywords: magnetic screw, motor, linear actuator, finite element method.

(2019 年 9 月 26 日受付, 2020 年 7 月 7 日再受付)

\section{1 緒言}

回転運動を直動運動に変換することが可能な送り ねじは, 搬送用装置など様々な分野で用いられている。 しかし，ボールねじなどの機械式の送りねじは，摩擦 による発熱, 摩耗, 振動・騒音, 低効率などの課題が 存在する。一方で, 磁気スクリュは磁力で力を伝達す るゆえに上記の問題は生じない[1]。さらに，磁気ばね による弾性や過負荷時に脱調する推力リミッタ機能を 持つ。そのため, 協働ロボットなどへの応用も期待さ れており，様々な磁気スクリュが提案されている。

しかし，磁気スクリュを駆動するためには，モータ が必要であり, システムの大型化が問題となる。その ため, 磁気スクリュとモータを一体化したスクリュ モータが提案されている。C. S. Cyusa らは, 磁気ナッ 卜の構造を有する回転子の内側に, 磁気ねじ型の並進 可動子を有する 2 可動子のスクリュモータを提案した [2]。可動子を 2 つ有しており, 構造が複雑でシステム の大型化につながる。回転子と並進可動子を有するス クリュモータは他にも報告されている $[3,4]$ 。 Y. Fujimoto らはアキシャルギャップの IPM 型スクリュ モータを提案した[5]。可動子, 固定子共にらせん型構 造をしており, 構造が複雑である。さらに, 可動子に

\footnotetext{
連絡先： 高原 一晶, テ565-0871 大阪府吹田市山田丘 2-1 大阪大学大学院工学研究科

e-mail: kazuaki.takahara@ams.eng.osaka-u.sc.jp

${ }^{* 1}$ 大阪大学大学院
}

永久磁石を有するため， ストローク長に応じて永久磁 石体積が増加し, 高コスト化につながる。 M. Sakai ら はラジアルギャップの IPM 型スクリュモータを提案 した[6]。M. Sakai らの提案構造も可動子に永久磁石を 有するため, ストローク長の増加に従って永久磁石体 積が増加し，コストが増加するという課題がある。

ストローク長による永久磁石体積の増加をなくす ため，本稿では固定子に永久磁石を配置し，可動子の 突極により変調された磁束を用いて駆動するスクリュ モータを提案する。変調波磁束を用いた Modulated 型

(M 型) スクリュモータの構造と動作原理を説明し, 有限要素解析を用いて IPM 型との特性比較を行う。

\section{2 基本構造と動作原理}

\section{$2.1 \mathrm{IPM}$ 型と $\mathrm{M}$ 型スクリュモータの構造}

IPM 型の基本構造を Fig. 1 に示し, 仕様を Table 1 に 示す。IPM 型は 3 相電機子巻線を有する固定子と永久 磁石を有するスクリュ型可動子から構成される。固定 子のティース先端には, Fig. 1(b)に示すようにらせん型 突極が設けられている。スクリュ型可動子は Fig. 1(c) に示すように，可動子表面にらせん型の突極が貼り付 けられている。Fig. 2(a)に示すように, X-Y 平面に着目 すると 3 相 IPM 型同期モータと同様の構造をしてお り, Y-Z (X-Z) 平面に着目した場合, Fig. 2(b)に示すよ うに IPM 型磁気スクリュと同様の構造をしている[7]。

次に, 本稿で提案する $\mathrm{M}$ 型の構造を Fig. 3 に示し, 仕様を Table 1 に示す。Fig. 3 に示すように，M型は永 


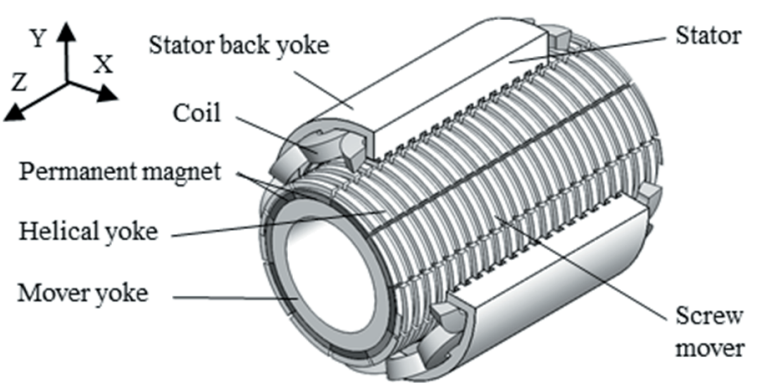

(a) Whole view.
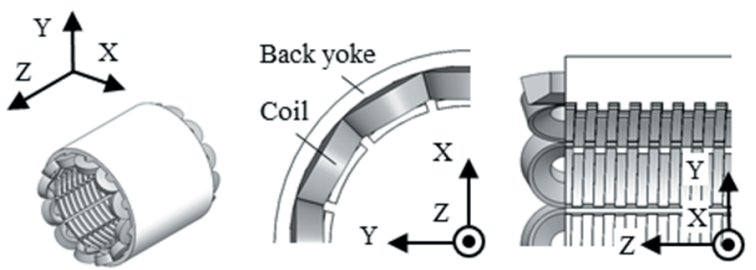

(b) Stator.

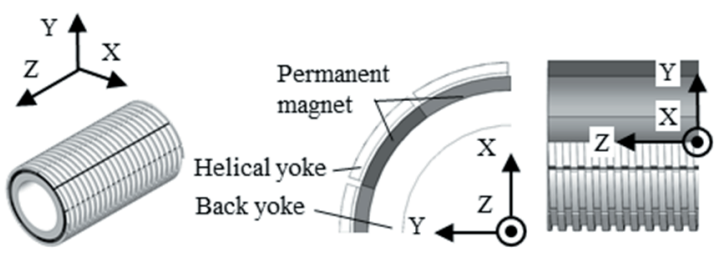

(c) Screw mover.

Fig. 1 Basic structure of the IPM-type screw motor.

Table 1 Specifications of screw motor.

\begin{tabular}{|c|c|c|}
\hline Item & IPM-type & M-type \\
\hline Outer diameter $[\mathrm{mm}]$ & \multicolumn{2}{|c|}{70} \\
\hline Stack length [mm] & \multicolumn{2}{|c|}{60} \\
\hline Number of coil turns & \multicolumn{2}{|c|}{20} \\
\hline Number of rotor poles & 10 & 16 \\
\hline Number of stator slots & \multicolumn{2}{|c|}{12} \\
\hline Herical pitch [mm] & \multicolumn{2}{|c|}{4} \\
\hline $\begin{array}{l}\text { Effective permanent magnet } \\
\text { volume }\left[\mathrm{mm}^{3}\right]\end{array}$ & 16,207 & 6067 \\
\hline $\begin{array}{l}\text { Parmanent magnet thickness } \\
{[\mathrm{mm}]}\end{array}$ & 2.0 & 1.4 \\
\hline Permanent magnet material & \multicolumn{2}{|c|}{$\mathrm{N} 48 \mathrm{SH}$} \\
\hline Core material & \multicolumn{2}{|c|}{$50 \mathrm{~A} 400$} \\
\hline
\end{tabular}

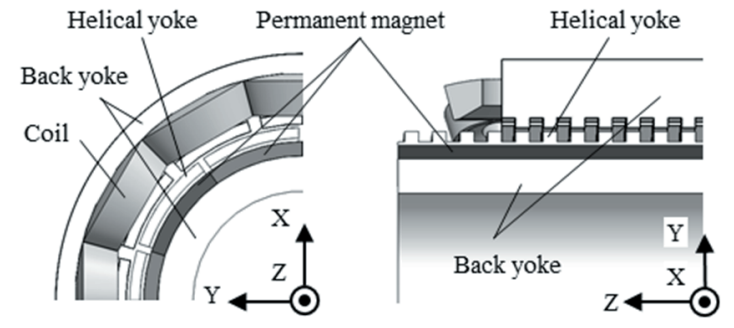

(a) X-Y plane.

(b) Y-Z plane

Fig. 2 Cross-sectional view of the IPM-type.

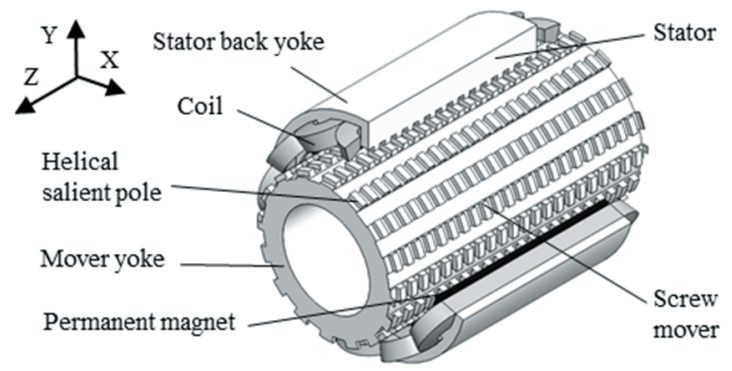

(a) Whole view.
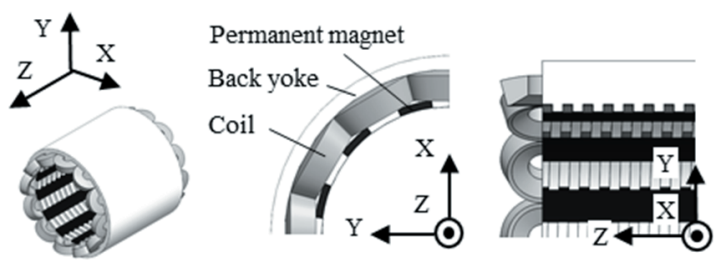

(b) Stator.

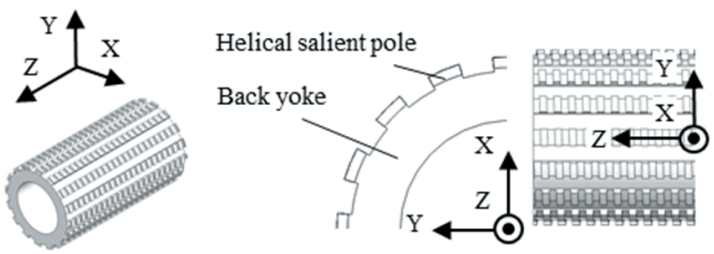

(c) Screw mover.

Fig. 3 Basic structure of the M-type screw motor.

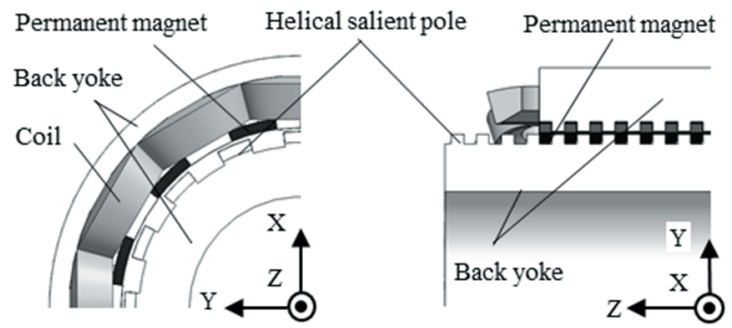

(a) X-Y plane.

(b) Y-Z plane

Fig. 4 Cross-sectional view of the M-type.

久磁石を有する固定子と，鉄心のみから構成されるス クリュ型可動子から構成されている。固定子には Fig. 3(b)に示寸ように 3 相の電機子巻線が施され, ティー ス先端にはらせん型の突極が設けられている。さらに, ティース開口角部には径方向に着磁された瓦型の永久 磁石が配置されている。固定子内径やコイル断面積を IPM 型と統一寸るため, M 型の瓦型永久磁石の厚みは $1.4 \mathrm{~mm}$ となっている。スクリュ型可動子には Fig. 3(c) に示すように，周方向に配置された突極の先端にらせ ん型の突極が設けられている。X-Y 平面に着目した場 合, Fig. 4(a)に示すように 3 相のバーニアモータと同様 


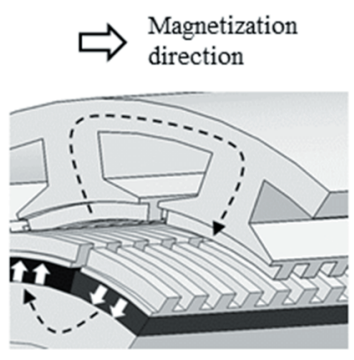

(a) X-Y plane.

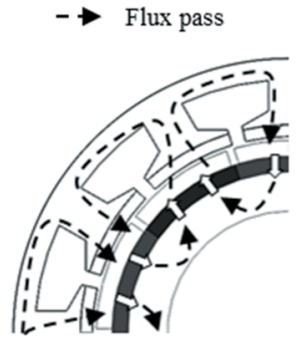

(b) Y-Z plane

Fig. 5 Magnetic circuit of the IPM-type.

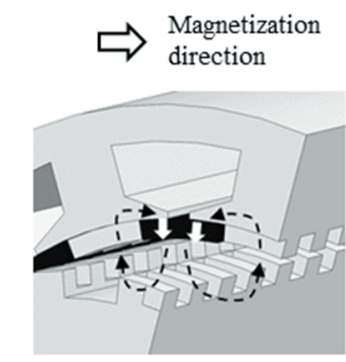

(a) X-Y plane.

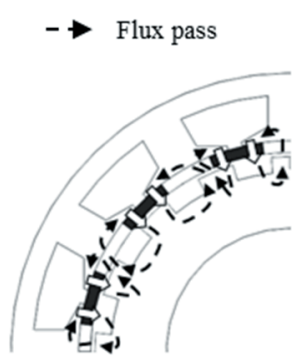

(b) Y-Z plane

Fig. 6 Magnetic circuit of the M-type.

の構造となっている[8]。Y-Z (X-Z) 平面に着目した場 合, Fig. 4(b)に示すようにコンシークエント型磁気スク リュと同様の構造をしている[9]。X-Y 平面における極 数と Y-Z (X-Z) 平面における突極のピッチは, IPM 型, $\mathrm{M}$ 型共に独立して決定可能である。

\section{2 動作原理}

次にそれぞれのスクリュモータの動作原理につい て説明する。スクリュモータの動作原理はモータパー トとスクリュパートに分けることが可能であるため, それぞれのパートごとに動作原理を説明する。

\subsubsection{IPM 型のスクリュパートの動作原理}

IPM 型スクリュパートの磁束の流れを Fig. 5(a)に示 す。Fig. 5(a)に示すように, 磁束は可動子の永久磁石か らスクリュ可動子のらせん型突極を経て固定子の ティースに入り, 鉄心を通り可動子に戻る。磁束が固 定子と可動子のらせん型突極を通過することにより， 磁気スクリュとして作用寸る[7]。このスクリュパート においては 1 条悋じだけでなく, 多条ねじにおいても 成り立つ。推力は固定子と可動子の直動と回転の電気 角位相差に応じて生じる。位相差が 0 の場合, スクリュ の電気角位相は直動方向の変位から次式のように算出 できる。

$$
\theta=\frac{2 \pi}{L} p
$$

ここで， $\theta$ はスクリュの回転角度， $L$ はスクリュの リード長， $p$ はスクリュの直動方向の変位である。 固定子と可動子間の相対変位がらせん型突極のピッ チの半分を超えた場合スクリュ型可動子は脱調し, 次の突極の位置まで可動子が移動する。

\subsubsection{IPM 型のモータパートの動作原理}

Fig. 2(a)に示したように，IPM 型スクリュモータの $\mathrm{X}-\mathrm{Y}$ 平面での構造は 3 相同期モータと同様の構造をし ている。そのため, 通常の 3 相同期モータと同様の動 作原理で可動子を回転させることが可能である[6]。

\subsubsection{M 型のスクリュパートの動作原理}

M 型スクリュモータのスクリュパートにおける磁 束の流れを Fig. 6(a)に示寸。固定子の永久磁石により 生じた磁束はティース先端のらせん型突極からエア ギャップに出て，可動子の突極と鉄心を経て再び固定 子へと戻る。磁束が固定子と可動子のらせん型突極を 通過することにより磁気スクリュとして作用する。こ のスクリュパートにおいては 1 条ねじだけでなく, 多 条ねじにおいても成り立つ。推力は IPM 型と同様に, 固定子と可動子の直動と回転の電気角位相差に応じて 生じる。また, 固定子と可動子間の相対変位がらせん 型突極のピッチの半分を超えた場合スクリュ型可動 子は脱調し, 次の突極の位置まで可動子が移動する。

\subsubsection{M 型のモータパートの動作原理}

M 型スクリュモータを回転させるために, 固定子永 久磁石による起磁力分布と可動子突極によるパーミア ンス分布による変調波磁束を用いる。すなわち, 電機 子巻線に 3 相交流を印加することによって発生する回 転磁界と，変調波磁束が同期して可動子が回転する。 ここで, 起磁力分布 $F$, パーミアンス分布 $P$ は以下の 式で表せるとする。

$$
\begin{gathered}
F=F_{S} \sin Z_{s} \theta \\
P=P_{0}+P_{r} \sin Z_{r} \theta
\end{gathered}
$$

ここで, $Z_{s}, Z_{r}$ はそれぞれ固定子のティースと可動子 の突極の極数であり， $F_{s}, P_{r}$ はそれぞれ起磁力分布 とパーミアンス分布の振幅, $P_{0}$ はパーミアンス分布 の平均值, $\theta$ は円周方向の機械角度である。変調波磁 


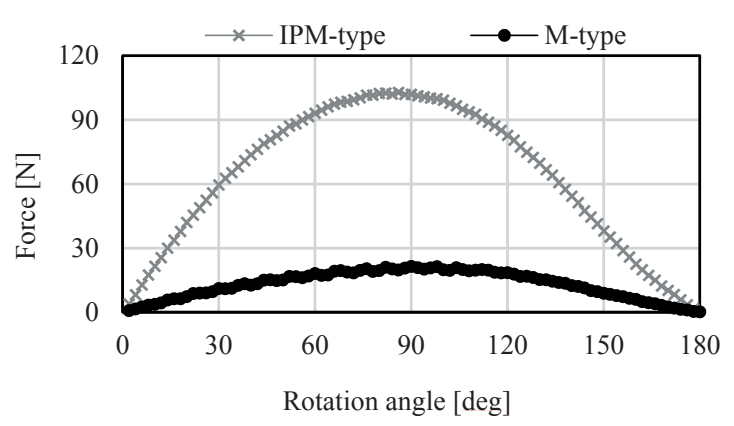

Fig. 7 Analysis result of transmission forces.

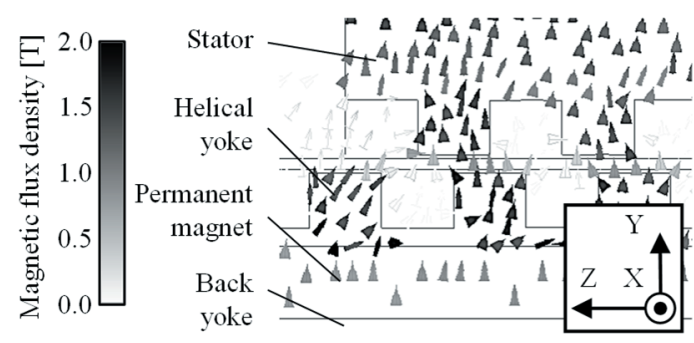

(a) IPM-type

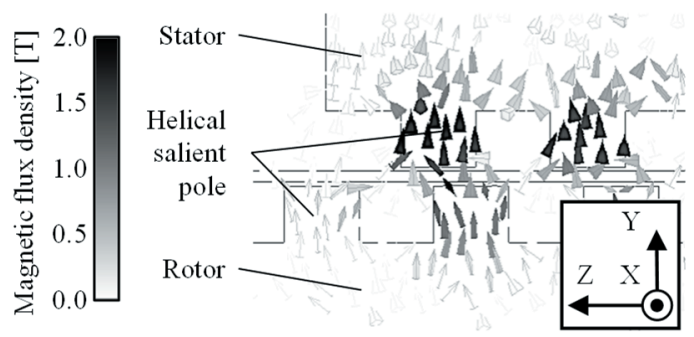

(b) M-type

Fig. 8 Magnetic flux vector distribution.

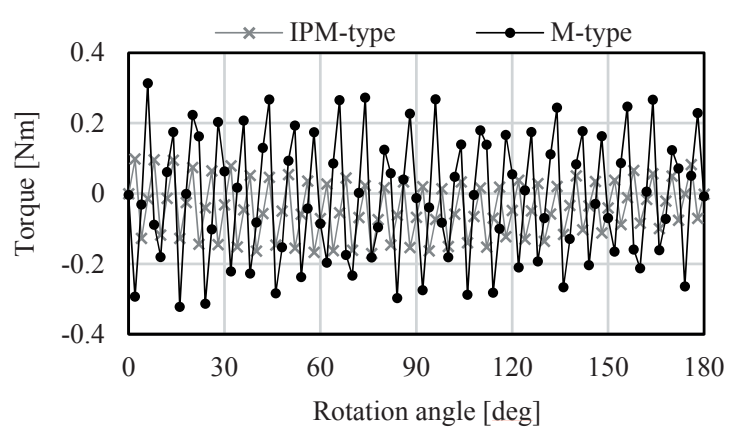

Fig. 9 Analysis result of torques.

束は起磁力とパーミアンスの積によって次式のよう に求められる。

$$
\begin{aligned}
F \times P= & F_{s} \sin Z_{s} \theta \times\left(P_{0}+P_{r} \sin Z_{r} \theta\right) \\
= & F_{s} P_{0} \sin Z_{s} \theta-\frac{1}{2} F_{s} P_{r} \cos \left\{\left(Z_{s}+Z_{r}\right) \theta\right\} \\
& \quad+\frac{1}{2} F_{s} P_{r} \cos \left\{\left(Z_{s}-Z_{r}\right) \theta\right\}
\end{aligned}
$$

可動子の突極数 $Z_{r}$ は式(4)右辺の第 2 項もしくは第 3 項が回転磁界と同期するように決定される。すなわち, 式(5)に示される極数の関係式が成り立つ。

$$
Z_{s} \pm Z_{r}=p
$$

ここで, $p$ は巻線の極対数である。

\section{FEM による推カ・トルク特性の評価}

\section{1 最大伝達推力, トルク, 鎖交磁束の評価}

最大伝達推力は可動子の Z 軸方向変位を固定し, 電 気角 1 周期分回転させることにより確認する。本稿で は電気角 $2 \mathrm{deg}$ ずつ回転させることとする。各モデル の推力の解析結果を Fig. 7 に示す。また, Fig. 8 に回転 角 $90 \mathrm{deg}$ における各モデルの Y-Z 断面での磁束密度べ クトル図を示す。Fig. 7 より, IPM 型の最大伝達推力 は約 $102.9 \mathrm{~N}, \mathrm{M}$ 型は約 $21.5 \mathrm{~N}$ であり， M 型の最大伝 達推力は IPM 型より約 79 \%減少した。固定子もしく は可動子と対向している永久磁石の体積に着目した場 合, $\mathrm{M}$ 型の永久磁石体積は IPM型と比較し $37 \%$ となっ ており，ストロークが $0 \mathrm{~mm}$ の場合の永久磁石体積当 たりの推力密度比は IPM 型の方が $\mathrm{M}$ 型の約 1.8 倍と なっている。IPM 型ではらせん型突極が可動子表面全 域に設けられている。それに対し，M型の場合はらせ ん型突極が可動子表面の約半分に設けられている。そ のため, IPM 型の永久磁石体積当たりの推力密度比が $\mathrm{M}$ 型の約 2 倍になっていると考えられる。Fig. 8 より, 可動子が回転した際に可動子の突極が Z 軸方向に移動 し，推力が発生していることがわかる。

次に, 各モデルの最大伝達推力確認時のトルクを Fig. 9 に示す。Fig. 9 より，トルクの peek-to-peek は IPM 型 で約 $0.27 \mathrm{Nm}, M$ 型で約 $0.64 \mathrm{Nm}$ であった。可動子と 固定子の最小公倍数が IPM 型で $30, \mathrm{M}$ 型で 24 であ り， $\mathrm{M}$ 型の方が最小公倍数が小さいためトルクのリッ プルが大きくなったと考えられる。また， M型のリッ プルはピーク值にばらつきが見られるが，バーニア型 においては複数の変調波磁束が生じるため，コギング トルクにも高調波成分が生じる[10]。Fig. 9 のトルクに は 1 次の成分のリップルがみられるが，これは磁気ね 


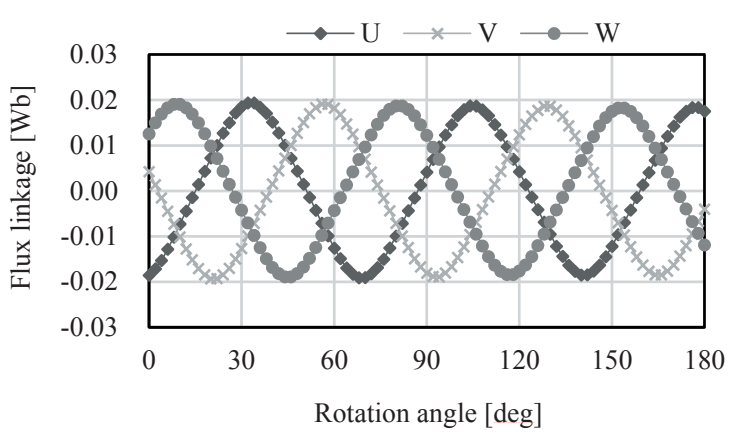

(a) IPM-type.

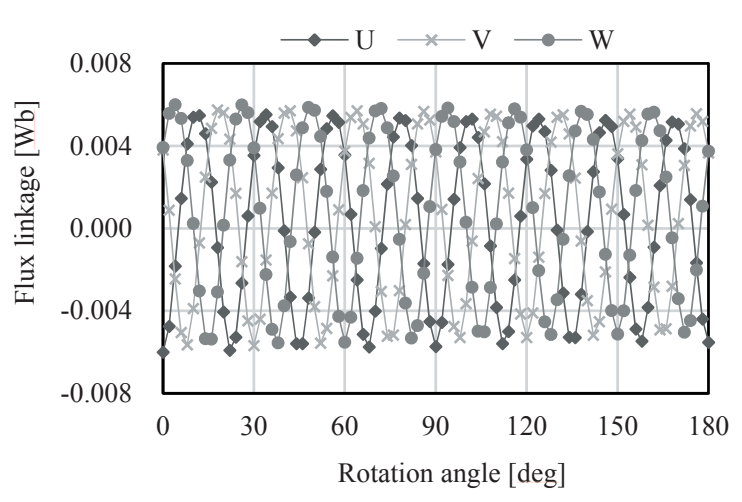

(b) M-type.

Fig. 10 Analysis result of flux linkage.

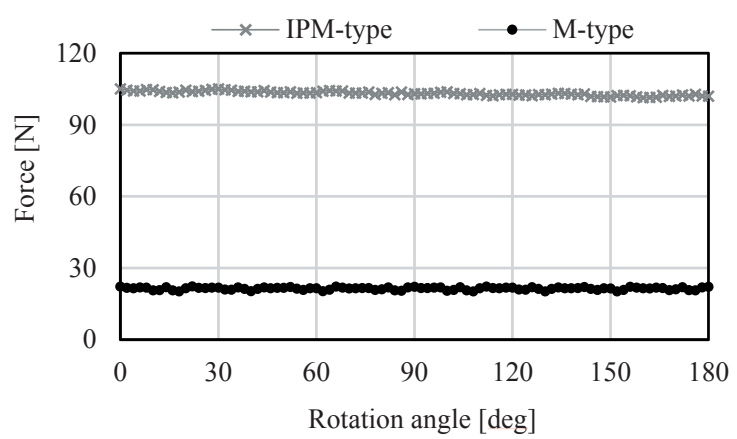

Fig. 11 Analysis result of transmission force.

じの位相差によって推力を発生させる場合に生じる反 トルクである。Fig. 9 のトルクの 1 次成分は IPM 型で $68 \mathrm{mNm}, \mathrm{M}$ 型で $16 \mathrm{mNm}$ であり, 最大推力と反トル クの 1 次成分の比は IPM 型が $1.5 \mathrm{~N} / \mathrm{mNm}, \mathrm{M}$ 型が 1.4 $\mathrm{N} / \mathrm{mNm}$ となった。

最後に，各モデルの鎖交磁束を Fig. 10 に示す。Fig. 10 より, 両モデルとも 3 相交流の鎖交磁束が得られて おり, 3 相同期モー夕と同様の磁気回路を構成できて いることがわかる。

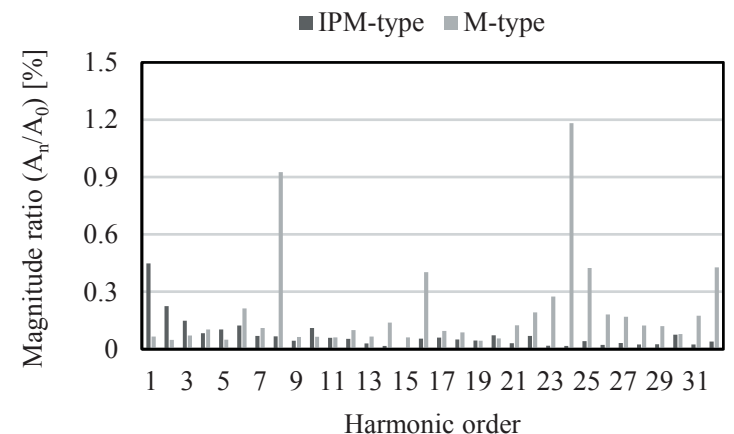

Fig. 12 Harmonic component of transmission force.

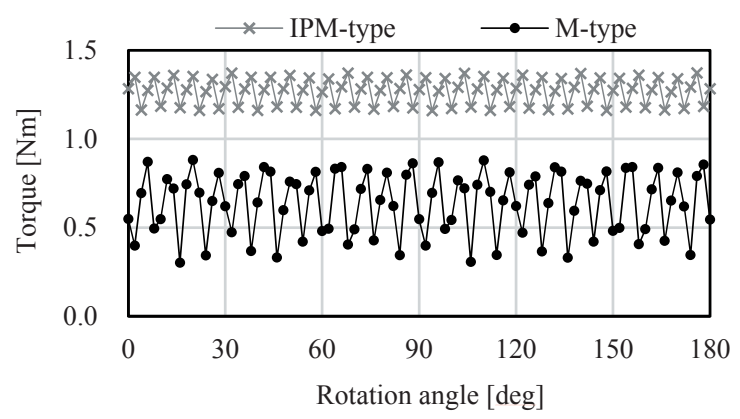

Fig. 13 Analysis result of torque.

\section{2 電流印加時の推力とトルク特性}

本稿では電流密度が $5 \mathrm{~A} / \mathrm{mm}^{2}$ となるように電流振幅 を決定し， $I_{d}=0$ 制御で電流を印加する。また， Z 軸方 向に位相差 $90 \mathrm{deg}$ を保ちながら, 強制並進移動と強制 回転させることとする。推力の解析結果を Fig. 11 に示 す。Fig. 11 より, 平均推力は Fig. 7 の最大伝達推力を 保っていることがわかる。これより，電流を印加して も推力には影響はなく, 固定子と可動子の磁気スク リュとしての位相差のみで推力が決定されることがわ かる。推カリップルは IPM 型で約 $3.6 \%$, M 型で約 10.0 \%となった。 $\mathrm{M}$ 型の推カリップルは IPM 型の約 2.8 倍となったが, スクリュモータとして機能している ことがわかる。 $\mathrm{M}$ 型の推力リップルが大きくなった原 因を確認するため, Fig. 11 の各モデルの推力を FFT し, 0 次成分の振幅に対する各次数成分の振幅の割合を Fig. 12 に示す。 $M$ 型においては 8 次と 24 次の成分が 特に出ている。8 次は可動子突極の次数, 24 次は可動 子突極と固定子スロット数の最小公倍数にあたる。 IPM 型では可動子極数に対応する成分が 10 次, 固定 子スロット数に対応寸る成分が 6 次であるがそれぞれ $0.1 \%$ ～M 型に比べ小さい。これは, 磁気スクリュと 


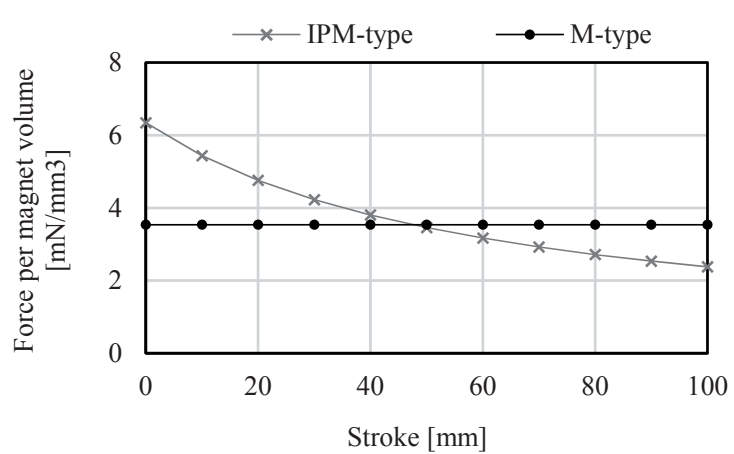

Fig. 14 Relationship between the force per permanent magnet volume and the stroke.

してのらせんに設けられた分割溝の大きさに起因する と考えられる。理想的には磁気ねじのらせんはすべて 連続であるが，実際には円周方向に分割されている。 IPM 型は分割溝が狭いため影響が大きく見られないが， $\mathrm{M}$ 型はモータの動作原理上分割溝が広く, 推力リップ ルの原因になっていると考えられる。また，IPM型は 1 次成分が $0.4 \%$ 出ているが, これは可動子の軸方向長 さが十分ではないため, 永久磁石が移動した影響が出 ていると考えられる。

次に, 各モデルの電流を印加した際のトルクを Fig. 13 に示す。Fig. 13 の各モデルのトルクを平均すると, IPM 型は $1.27 \mathrm{Nm}, \mathrm{M}$ 型は $0.64 \mathrm{Nm}$ であった。ただし, 平均算出には 180 度点のデータは除いている。各モデ ルのトルクはそれぞれ最大伝達推力を出力可能である ことがわかる。そのため, モータパートをより小型化 することも可能である。 $\mathrm{M}$ 型のトルクリップルはコギ ングトルク同様に高調波成分が重畳されていること， ステップ角度が高調波成分に対し粗いことによりばら つきが大きくなっている。

\section{3 ストローク長と永久磁石体積当たりの推力密度}

IPM 型と $M$ 型のストローク長と永久磁石体積当た りの推力密度特性の関係を比較する。永久磁石当たり の推力密度は径や永久磁石の材料, $\mathrm{M}$ 型の可動子突極 の幅等様々なパラメータに依存する。そのため, 本稿 の比較はあくまでも本稿で用いた各仕様における結果 である。本稿では, 固定子の積厚は固定し, 可動子の 軸長は固定子の積厚にストローク長を加えた長さとす る。ストローク長と永久磁石体積当たりの推力密度の 関係を Fig. 14 に示す。Fig. 14 より, ストローク長が約 $50 \mathrm{~mm}$ 以上の場合, 本稿で提案した $\mathrm{M}$ 型の方が IPM 型に比べ永久磁石体積当たりの推力密度が高いことが
わかる。

\section{4 結言}

本稿では，固定子にのみ永久磁石を有し，変調波磁 束を用いて駆動するスクリュモータを提案した。基本 構造と動作原理について説明し，3 次元の有限要素法 による磁場解析により推力・トルク特性を確認した。 本稿で用いた各仕様において, 提案した $\mathrm{M}$ 型は IPM 型と比較して，ストローク長が $50 \mathrm{~mm}$ 以上の範囲にお いて永久磁石体積当たりの推力密度が高いことがわか り，有効性を示せた。

\section{参考文献}

[1] X. G. Garcia, H. Beppu, M. Tanaka and Y. Okawa, A Vial Loading System with Non-Contact Drive Mechanism Using Magnetic Technology, Technical Journals of Azbil Corporation, 2017.

[2] C. S. Cyusa and Y. Fujimoto, Enactment Based Direct-Drive Test of a Novel Radial-Gap Helical RotLin Machine, IEEE Transactions on Industry Applications, Vol. 54, No. 2, pp. 1273-1282, 2017.

[3] K. Lu and W. Wu, Electromagnetic Lead Screw for Potential Wave Energy Application, IEEE Transactions on Magnetics, Vol. 50, No. 11, 2014.

[4] J. Wang, K. Atallah and W. Wang, Analysis of a Magnetic Screw for High Force Density Linear Electromagnetic Actuators, IEEE Transactions on Magnetics, Vol. 47, No. 10, pp. 4477-4480, 2011.

[5] Y. Fujimoto, T. Suenaga and M. Koyama, Control of an Interior Permanent Magnets Screw Motor with Power-saving Axial-gap Displacement Adjustment, IEEE Transactions on Industrial Electronics, Vol. 61, No. 7, 2014.

[6] M. Sakai, K. Hirata and Y. Nakata, Characteristics Analysis of a Herical Teethed Linear Actuator, International Jounal of Applied Electromagnetics and Mechanics, Vol. 50, No. 1-2, pp. 571-578, 2016

[7] R. J. A. Paul, Magnetic rotary-to-linear converter, IEE Journal on Electric Power Applications, Vol. 1, No. 4, pp. 115-116, 1978.

[8] Y. Nakata, T. Fujimoto, H. Ishiguro, and K. Hirata, Desi gn and optimization of a novel small-sized linear vernier motor without mover magnets for artificial muscle appli cations," Proceedings of the IEEE INTERMAG 2012, B G-01, 2012.

[9] A. Heya, Y. Nakata, M. Sakai, H. Ishiguro, and K. Hira ta, "Force Estimation Method for a Magnetic Lead-Scre w-Driven Linear Actuator", IEEE Transactions on Magn etics, Vol. 54, No. 11, Art. No. 8207805, 2018.

[10] Y. Chen, X. Zhu, L. Quan, Z. Xiang, Y. Du, and X. B u, "A V-Shaped PM Vernier Motor With Enhanced Flux -Modulated", IEEE Transactions on Magnetics, Vol. 54, No. 11, Art. No. 8203804, 2018. 